\title{
Forest and other land cover assessment in Nepal using Collect Earth
}

\author{
A. Khadka ${ }^{1 *}$, M. Dhungana ${ }^{2}$, S. Khanal ${ }^{3}$ and D. K. Kharal ${ }^{4}$
}

Periodic monitoring of land cover is essential to examine the total extent and changes over time. Information derived from forest and other land cover analysis provides key input for policy formulation and management decisions. Land cover patterns on the Earth are constantly being changed by different human activities, thereby influencing biophysical processes. Analysis and mapping of land cover are important aspects in management, planning and monitoring of forest resources. Thus, we designed this study to assess national-level forest and land cover using the Openforis Collect Earth and compare the results with other assessments. We generated a number of systematic sampling points across the country and visually interpreted each of them on this Platform to assess the land cover type. Furthermore, we adopted six land cover classes as prescribed by the IPCC Good Practice Guidance. Our study provided the current status of forest and other different land cover classes. Forest occupied 6.54 million ha $(44.47 \%)$ followed by Other land 4.22 million ha $(28.68 \%)$ of the total area of Nepal, respectively. Besides, Cropland, Settlement, Wetland and Grassland covered 3.22 million ha, 0.17 million ha, 0.18 million ha and 0.38 million ha, respectively. The overall accuracy of the interpretation of all the land cover classes was found to be more than $98 \%$. Comparing the results with the past studies, the calculated results of Forest, Cropland, Settlement and Wetland were found to be reliable for reporting purpose. However, further studies are necessary to generate more reliable results in terms of the Other land and Grassland.

Keywords: Collect Earth, forest resource assessment, land cover, visual interpretation

$\mathrm{R}$ emote sensing is a common approach for monitoring land-use and land use change to quantify the impacts on the Earth's system. Over the past decades, significant changes in the remote sensing field have made land monitoring more cost-effective and technically feasible. Access of moderate to high-resolution satellite imageries such as Landsat, Sentinel and open source software have facilitated the remote sensing users to monitor land resources and provided the end-use products.

Land cover patterns on the Earth have been impacted by several anthropogenic activities and thus, influence the biophysical processes ( $\mathrm{Li}$ and Shao, 2014). A variety of social and biophysical factors are responsible for land use and land cover change at several spatial- and temporal-levels (Briassoulis, 2004). For instance, conversion of natural ecosystems for agricultural practices has been a primary factor in land use and land cover change (Ramankutty and Foley, 1999). Although the information derived from forest and other land cover analysis provides a key input for policy formulation and management decisions, a handful of national-level forest and land cover assessments have been conducted in Nepal. However, the approach adopted for those

1 Forest Research and Training Centre (FRTC), Babarmahal, Kathmandu, Nepal, *E-mail: ananda.khadka@nepal.gov.np, anandakhadka@gmail.com

2 Ministry of Forests and Environment, Singh Durbar, Kathmandu, Nepal

3 Hawkesbury Institute for the Environment, Western Sydney University, Australia

4 Ministry of Industry, Tourism, Forest and Environment, Gandaki Province, Pokhara, Nepal 
assessments were not consistent and comparable to each other (Figure 1).

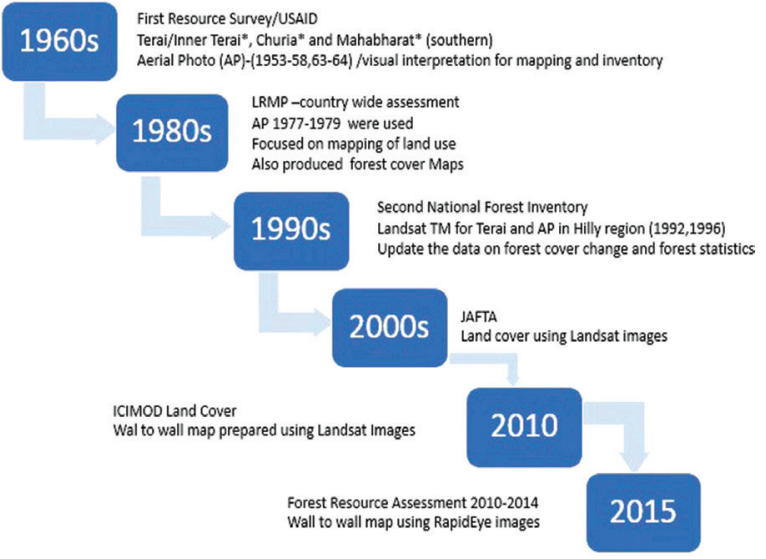

Figure 1: History of land cover assessments in Nepal

Notes: 1) * different physiographical regions of Nepal; 2) LRMP: Land Resources Mapping Project, JAFTA: Japan Foresters' Technical Association, and ICIMOD: International Centre for Integrated Mountain Development

Periodic monitoring of land cover is essential to examine the total extent and changes over time. Thus, analysis and mapping of land cover play an important role in management, monitoring and planning of land resources (Aspinall and Hill, 2007; Foody and Atkinson, 2003). In this regard, this study aimed to analyze the forest and land cover of Nepal using the Openforis Collect Earth and compare the results with other assessments.

\section{Materials and methods}

\section{Study area}

The study area covers the entire area of Nepal which is located between $26^{\circ} 22^{\prime}-30^{\circ} 27^{\prime} \mathrm{N}$ latitudes and $80^{\circ} 04^{\prime}-88^{\circ} 12^{\prime} \mathrm{E}$ longitudes (Figure 2 ). It has a considerable variation in elevation ranging from flat plains as low as $70 \mathrm{~m}$ above the sea-level in the south to $8,848 \mathrm{~m}$ (Mt. Everest) on the north (LRMP, 1986). Politically, the country is divided into seven federal states and 77 districts. The temperature and precipitation vary with the vertical terrain which consists of 118 ecosystems, 75 vegetation types, and 35 types of forest (MoFSC, 2014). Apart from the topographical, meteorological, and socio-economic variations, it has a diverse and complex land cover (Bhattarai et al., 2009). The major land cover types mainly include forests (broad-leaved, needle-leaved, and mixed), croplands, Shrub-lands, grasslands, bare lands, and permanent ice/snow (Wang, 2004; Uddin et al., 2014). The study was conducted in 2018.

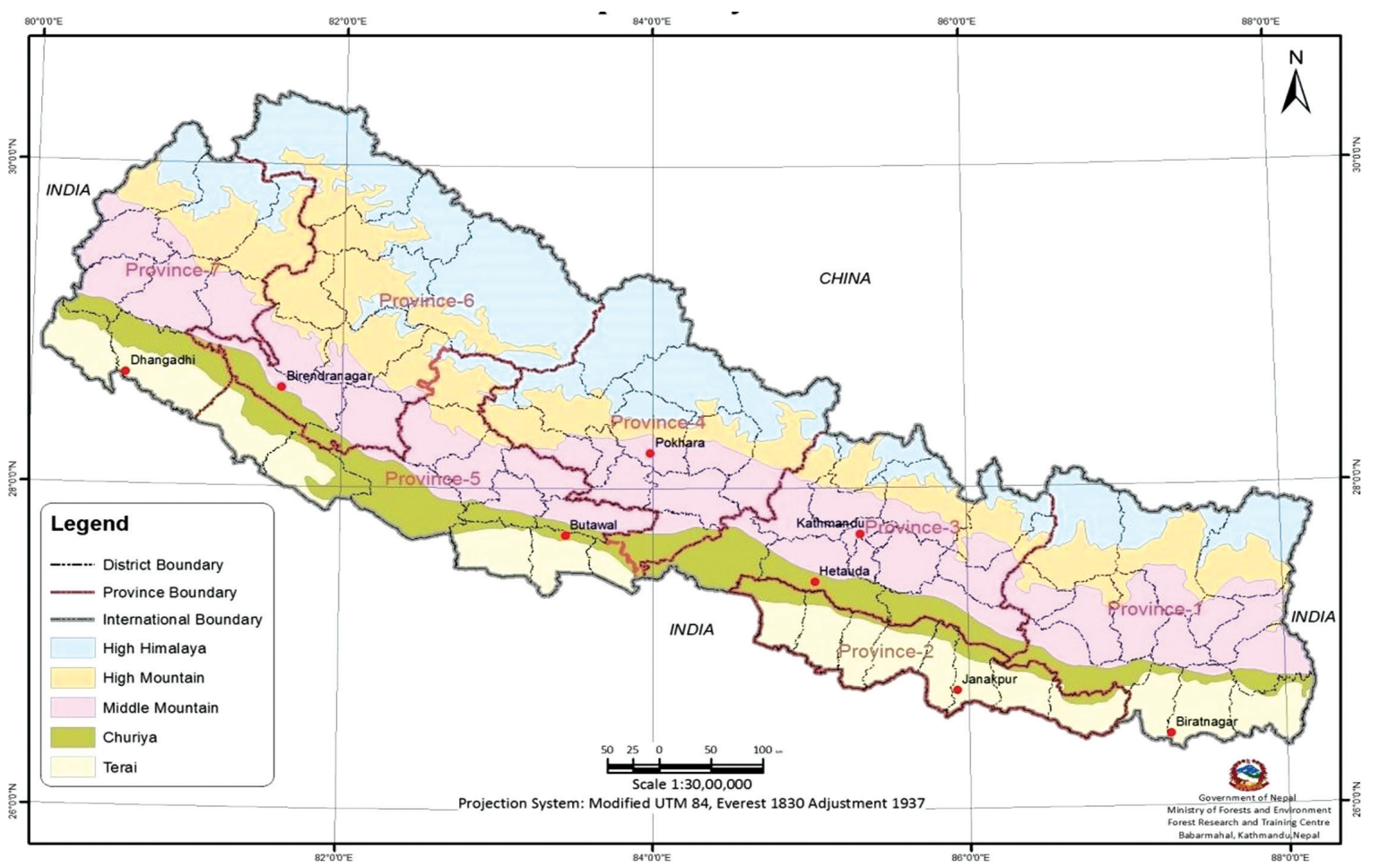

Figure 2: Topographical map of Nepal 


\section{Review of different classification methods}

Several approaches have been used in land cover classification and analysis. Uddin et al., (2014) adopted a harmonized and standardized classification scheme with 12 classes using the land cover classification system (LCCS) while developing the 2010 national land cover database for Nepal. They have adopted the Geographic Object-based Image Analysis (GEOBIA) technique for image classification. GEOBIA is a methodological framework for the machinebased interpretation of complex classes defined by spectral, spatial, contextual, and hierarchical properties (Duro et al., 2012). Lei et al. (2017) used an object-based classification method to produce the Nepal Cover-2010 product and adopted a two-level classification system with 8 and 31 classes at the first and second level, respectively. Conversely, a study on land cover of the Asmara region in Eritrea adopted both pixel-based and object-oriented classifiers to compare the results from two different approaches wherein the overall accuracy for an object-based approach was found to be higher $(85 \%)$ than that of the pixel-based approach (78\%, Araya and Hergarten, 2008). Presently, a number of open-source software and free satellite imageries are available for land use/ land cover analysis (Table 1), out of which the Collect Earth is more comprehensive with varied functionalities as it provides instant access to both very-high spatial and very-high temporal resolution data within a simple framework built upon Google technologies (Openforis, 2018).

Table 1: Overview of different freely available softwares for land use/ land cover analysis

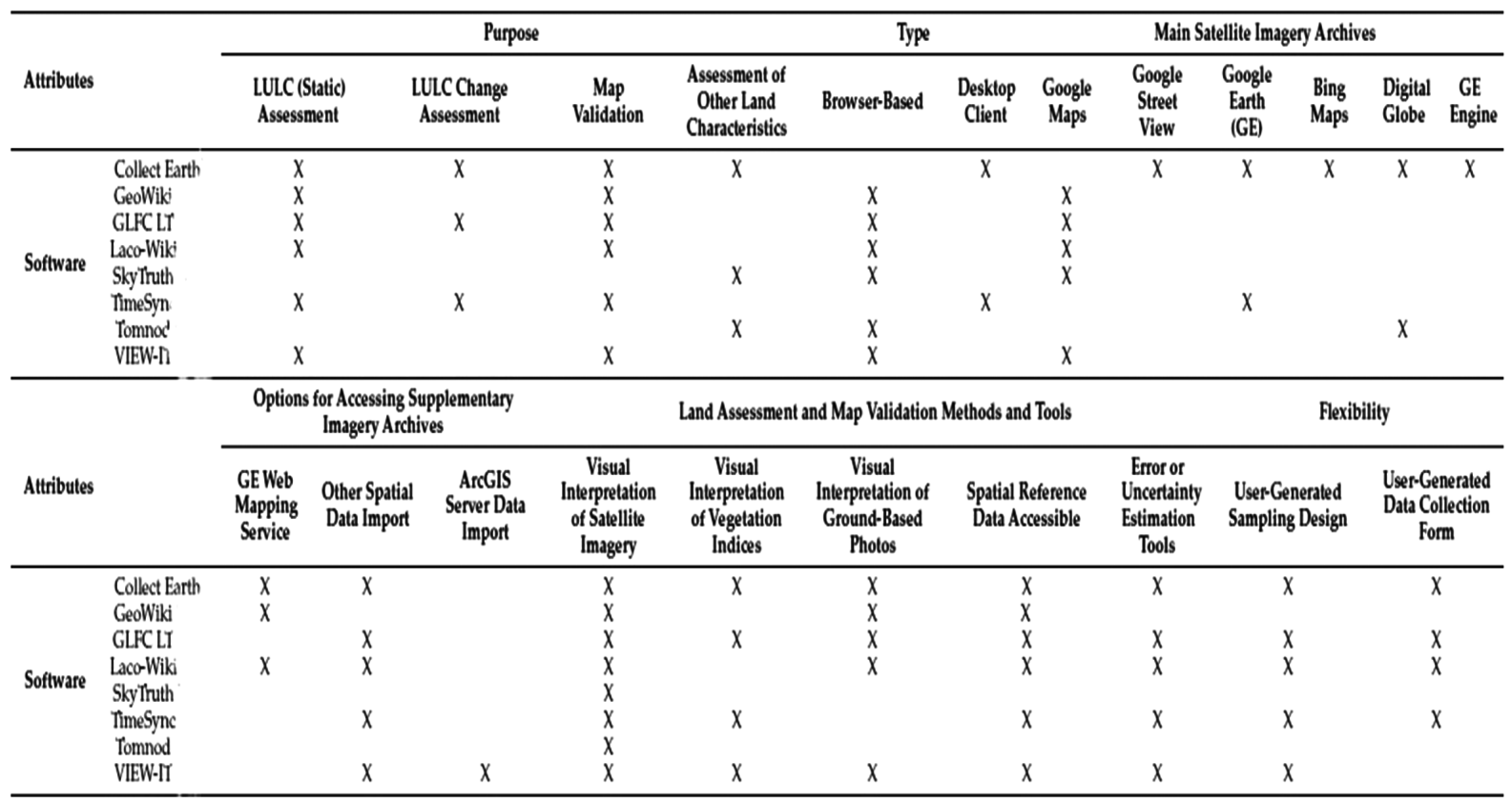

Source: Bey et al. (2016)

\section{Land cover classes}

Altogether, 36,843 sample points were generated systematically at a spacing of $2 \mathrm{~km} \times 2 \mathrm{~km}$ grid over the map of Nepal, out of which 36,773 were visually interpreted on the Openforis Collect Earth to assess the land cover type. Collect Earth, an open-source tool developed by the Food and Agriculture Organization of the United Nations, is used to facilitate land data collection, management and analysis (Openforis, 2018). It can be also used for a wide variety of purposes including land cover assessments, national forest inventories and quantifying deforestation.

Adoption of land cover classes depends on the purpose of assessment. Thus, the classes which are used at national, regional and/or international levels are rarely consistent. Consequently, various studies conducted on the assessment of land use/land cover in Nepal in different years had adopted varied types of land use/ land cover classes (Table 2). 
Table 2: Land use/ land cover classes used in different land use studies in Nepal

\begin{tabular}{l|l|l|} 
Project & Organisation & Land Use/ Land Cover Classes \\
\hline First NFI (1960s) & FORESC & $\begin{array}{l}\text { [7 Classes]: 1. Forest, 2. Cropland, 3. Grassland, 4. Urban } \\
\text { areas, 5. Water bodies, 6. Badly eroded lands, and } \\
\text { 7. Barren lands }\end{array}$ \\
\hline LRMP (1970s/80s) & Survey Dept. & $\begin{array}{l}\text { [5 Classes]: 1. Cultivated land, 2. Non-cultivated land, } \\
\text { 3. Grazing (Grassland) area, 4. Forest and shrub area, and } \\
\text { 5. Rocks, ice, water bodies, settlements and others }\end{array}$ \\
\hline WECS (1988) & WECS & $\begin{array}{l}\text { [6 Classes]: 1. Forest, 2. Shrub-land, 3. Grassland, } \\
\text { 4. Cultivated land, 5. Non-cultivated Inclusion, and } \\
\text { 6. Other land }\end{array}$
\end{tabular}

$\begin{array}{ll}\text { MPFS (1988) } & \text { [6 Classes]: 1. Forest, 2. Shrub-land, 3. Grassland, } \\ \text { 4. Cultivated land, 5. Non-cultivated Inclusion, and } \\ \text { 6. Other land }\end{array}$

\begin{tabular}{l|l|l|}
\hline $\begin{array}{l}\text { Second NFI } \\
(1989-1992)\end{array}$ & DFRS & [3 Classes]: 1. Forest, 2. Shrub-land, and 3. Non-forest \\
\hline $\begin{array}{l}\text { Land Cover } \\
\text { Mapping (2010) }\end{array}$ & ICIMOD & $\begin{array}{l}\text { [7 Classes]: 1. Forest, 2. Shrub-land, 3. Grassland, } \\
\text { 4. Agriculture, 5. Barren areas, 6. Snow, and 7. Built-up } \\
\text { areas }\end{array}$ \\
\hline $\begin{array}{l}\text { FRA Nepal } \\
(2010-2014)\end{array}$ & DFRS/FRA & $\begin{array}{l}\text { [3 Classes]: 1. Forest, 2. Other Wooded Land, and 3. Other } \\
\text { land }\end{array}$
\end{tabular}

Topographic

Mapping (1995)

Survey Dept.

[7 Classes]: 1. Agriculture, 2. Built-up area, 3. Forest,

4. Riverine and lake areas, 5. Shrub and grassland,

6. Snow/glaciers, and 7. Others

[11 Classes]: 1. Agriculture, 2. Residential areas,

Land Use Policy

(MoLRM, 2015)

MoLRM
3. Commercial areas, 4. Industrial areas, 5. Mines,

6. Cultural heritage areas, 7. Water bodies, 8 . Forest,

9. Public-use zones, 10. Construction-material extraction areas, and 11. Others
Note: NFI: National Forest Inventory; LRMP: Land Resource Mapping Project; WECS: Water and Energy Commission Secretariat; MPFS: Master Plan for the Forestry Sector; FRA: Forest Resource Assessment; MoFSC: Ministry of Forests and Soil Conservation; DFRS: Department of Forest Research and Survey; ICIMOD: International Centre for Integrated Mountain Development; MoLRM: Ministry of Land Reform and Management.

In this study, we adopted the land cover classes prescribed in the "Good Practice
Guidance for Land Use, Land Use Change and Forestry" developed by the International Panel on Climate Change (IPCC, 2003). The IPCC has broadly classified land cover classes into six categories (Table 3). Those categories can be considered as top-level for designating land areas within a country, and are consistent with the IPCC Guidelines and the requirements of the Kyoto Protocol (IPCC, 2003). Nevertheless, the land cover/land use classes can be further subdivided as per the national requirements. 
Table 3: Top-level land categories prescribed in the Good Practice Guidance of IPCC

\begin{tabular}{|c|l|l|}
\hline S.N. & $\begin{array}{l}\text { Land } \\
\text { Categories }\end{array}$ & Description \\
\hline 1. & Forest land & $\begin{array}{l}\text { This category includes all lands with woody vegetation consistent with } \\
\text { thresholds used to define forest land in the national GHG inventory, sub- } \\
\text { divided into managed and unmanaged, and also by ecosystem type as specified } \\
\text { in the IPCC Guidelines. It also includes systems with vegetation that currently } \\
\text { fall below, but are expected to exceed, the threshold of the forest land category. }\end{array}$ \\
\hline 2. & Cropland & $\begin{array}{l}\text { This category includes arable and tillage lands and agro-forestry systems } \\
\text { where vegetation falls below the thresholds used for the forest land category, } \\
\text { consistent with the selection of national definitions. }\end{array}$
\end{tabular}

3. Grassland This category includes rangelands and pasture lands which are not considered as cropland. It also includes systems with vegetation that falls below the thresholds used in the forest land category and are not expected to exceed, without human intervention, the threshold used in the forest land category. The category also includes all grasslands from wildlands to recreational areas as well as agricultural and silvi-pastoral systems, subdivided into managed and unmanaged consistent with national definitions.

4. Wetlands This category includes lands which are covered or saturated by water for all or part of the year (e.g. peatland) and which do not fall into the forest land, cropland, grass land or settlements categories. The category can be subdivided into managed and unmanaged according to national definitions. It includes reservoirs as managed sub-division and natural rivers and lakes as unmanaged sub-divisions.
5. Settlements This category includes all developed lands including transportation infrastructure and human settlements of any size, unless they are already included under other categories. This should be consistent with the selection of national definitions.
6. Other land This category includes bare soil, rock, ice, and all unmanaged land areas that do not fall into any of the other five categories. It allows the total of identified land areas to match the national area, where data are available.

Source: IPCC (2003)

\section{Accuracy assessment}

Although accuracy assessment is important for traditional remote sensing techniques, with the advent of more advanced digital satellite remote sensing the necessity of performing an accuracy assessment has received new interest (Congalton, 1991). Accuracy assessment in any study is considered as an integral part. It should usually be performed with reference to some ancillary data such as aerial photographs, previously prepared maps or even high-resolution satellite imagery or field verification. However, since the results of this study were not compared with other ancillary data and also could not generate sufficient data from field verification, an error matrix approach was performed on the individual land cover classes interpreted (Figure 3).

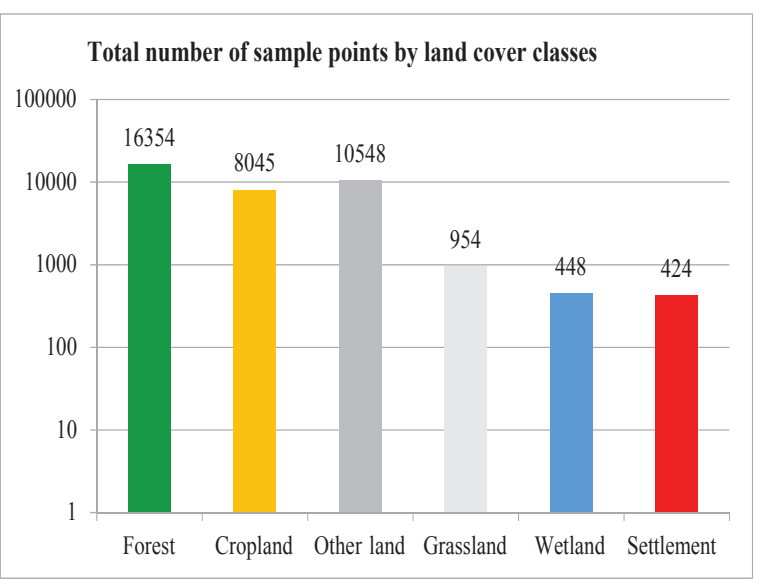

Figure 3: Total numbers of sample points by land cover classes 
A set of around $5 \%$ of the total sample points $(1,871)$ was selected systematically at an interval of 20 with a random start as test data sets. The reason behind the systematic selection of sample points was to incorporate data from all physiographic regions. The data were more carefully interpreted by an independent expert. The outcomes from those independent visual interpretations of the same sample points were arranged as a confusion matrix, and the overall accuracy of the interpretation was calculated.

\section{Results and discussion}

\section{Current land cover status of Nepal}

The results from this study provide the current status of forest and other different land cover classes. Forest occupies 6.54 million ha which is equivalent to $44.47 \%$ of the total area of Nepal (Figure 4). Secondly, Other land occupies 4.22 million ha, equivalent to $28.68 \%$ of the total area of the country. Then after, Cropland occupies 3.22 million ha which is $21.88 \%$ of the total area of the country. Settlement and Wetland, on the other hand, cover 0.17 million ha and 0.18 million ha representing $1.15 \%$ and $1.22 \%$ of the total area of the country, respectively. Regarding Grassland, only 0.38 million ha (equivalent to $2.60 \%$ of the country area) are estimated in this assessment.

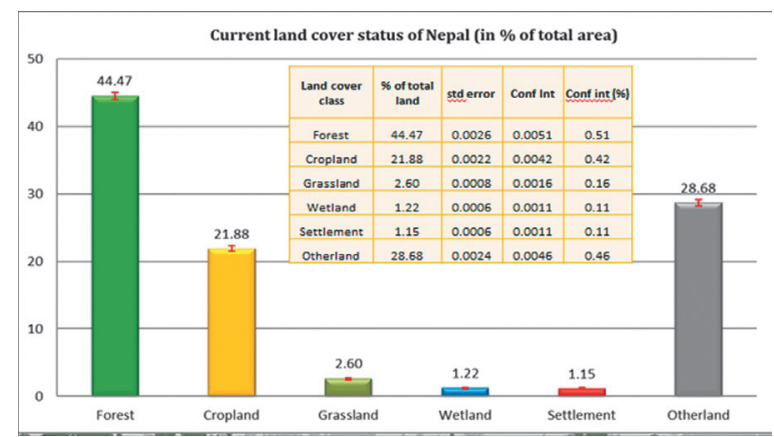

Figure 4: Current land cover status of Nepal

\section{Forest cover of Nepal}

This study has revealed the present forest cover of Nepal to be $6.54 \mathrm{~m}$ ha which is equivalent to $44.47 \%$ of the total area of the country. According to the latest Forest Resource Assessment of Nepal (FRA 2010-2014), Forest and Other Wooded Land covered 5.96 and 0.65 million ha respectively which together occupied $44.74 \%$ of the total area of the country (DFRS, 2015). Table 4 below highlights the comparison of forest cover assessed from this study with the ones obtained from the past assessments conducted in Nepal.

Table 4: Forest cover of Nepal as assessed from different assessments

\begin{tabular}{|l|l|l|l|l|l|l|l|l|l|}
\hline $\begin{array}{l}\text { Land } \\
\text { cover }\end{array}$ & $\begin{array}{l}\text { LRMP } \\
\mathbf{1 9 7 8} / 79\end{array}$ & $\begin{array}{l}\text { NRSC } \\
\mathbf{1 9 8 4}\end{array}$ & $\begin{array}{l}\text { Master } \\
\text { Plan } \\
\mathbf{1 9 8 5 / 8 6}\end{array}$ & $\begin{array}{l}\text { WECS } \\
\mathbf{1 9 8 8}\end{array}$ & $\begin{array}{l}\text { NFI } \\
\mathbf{1 9 9 4}\end{array}$ & $\begin{array}{l}\text { Survey } \\
\text { Dept. } \\
\mathbf{1 9 9 5}\end{array}$ & $\begin{array}{l}\text { JAFTA } \\
\mathbf{2 0 0 0 / 0 1}\end{array}$ & $\begin{array}{l}\text { FRA } \\
\mathbf{2 0 1 0}-\mathbf{2 0 1 4}\end{array}$ & $\begin{array}{l}\text { This } \\
\text { study } \\
\mathbf{2 0 1 8}\end{array}$ \\
\hline $\begin{array}{l}\text { Forest } \\
\text { Sh }\end{array}$ & $35.9^{*}$ & 37.4 & 38.1 & 29 & 38.3 & 37.3 & 40.36 & 44.47 \\
\hline $\begin{array}{l}\text { Shrub } \\
4.7\end{array}$ & - & 4.8 & 4.7 & 10.6 & - & 9.3 & $4.38^{* *}$ & - \\
\hline $\begin{array}{l}\text { Forest } \\
+ \\
\text { Shrub }\end{array}$ & 42.7 & $35.9^{*}$ & 42.2 & 42.8 & 39.6 & 38.3 & 46.6 & 44.74 & 44.47 \\
\hline
\end{tabular}

*Including some shrub areas; **Other Wooded Land

Source: DFRS (2015)

\section{Accuracy assessment}

Comparison of the test sample points $(1,871)$ against the subset of large regular plots for the same showed that the interpretation was consistent. The overall accuracy of the interpretation of all the land cover classes was found to be $98.5 \%$. The classwise accuracies are presented in Table 5. 
Table 5: Accuracy of visual interpretations

\begin{tabular}{|c|c|c|c|c|c|c|c|c|c|}
\hline & & & cur & cy & $\begin{array}{l}\text { rpret } \\
\text { sseess }\end{array}$ & $\begin{array}{l}\text { tion } \\
\text { ten }\end{array}$ & & & \\
\hline & & $\frac{\text { 를 }}{\frac{1}{0}}$ & 莸 & 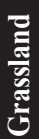 & 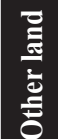 & 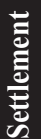 & 를 & हَّ & 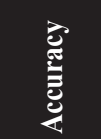 \\
\hline & Cropland & 438 & 4 & 0 & 1 & 1 & 1 & 445 & $98.43 \%$ \\
\hline & Forest & 2 & 821 & 0 & 1 & 0 & 0 & 824 & $99.64 \%$ \\
\hline స్తై & Grassland & 0 & 0 & 6 & 1 & 0 & 0 & 7 & $85.71 \%$ \\
\hline 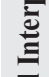 & $\begin{array}{l}\text { Other } \\
\text { land }\end{array}$ & 2 & 1 & 5 & 540 & 0 & 1 & 549 & $98.36 \%$ \\
\hline. & Settlement & 0 & 0 & 0 & 1 & 23 & 0 & 24 & $95.83 \%$ \\
\hline 0 & Wetland & 0 & 1 & 0 & 1 & 0 & 20 & 22 & $90.91 \%$ \\
\hline & Total & 442 & 827 & 11 & 545 & 24 & 22 & 1,871 & \\
\hline
\end{tabular}

Several studies have been conducted in the past with an aim to quantify the status of land use/ land cover. Figures 5-8 represent the proportion of the country by different land cover/landuse classes from those studies. However due to inconsistencies on methods and adopted classes among those studies, a thorough comparison of different time periods is rather difficult.

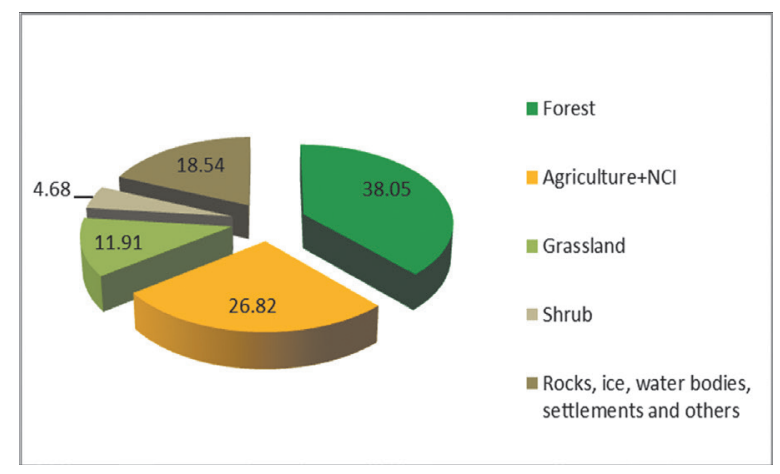

Source: LRMP, 1986

Figure 5: Land use status by LRMP in 1986

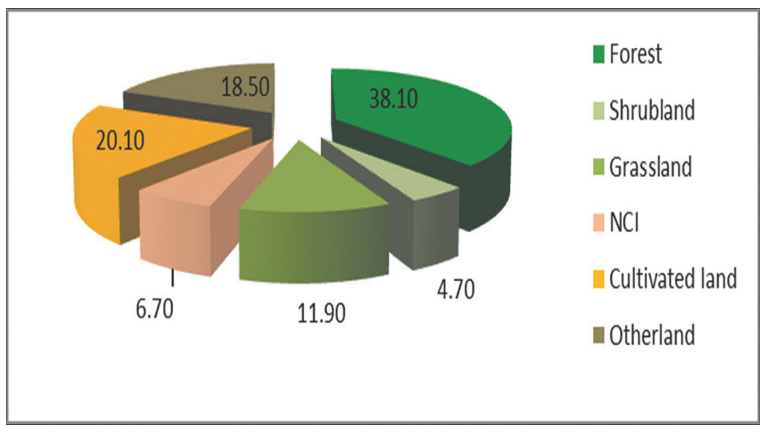

Source: WECS, 1988

Figure 6: Land use status by WECS in 1978/79

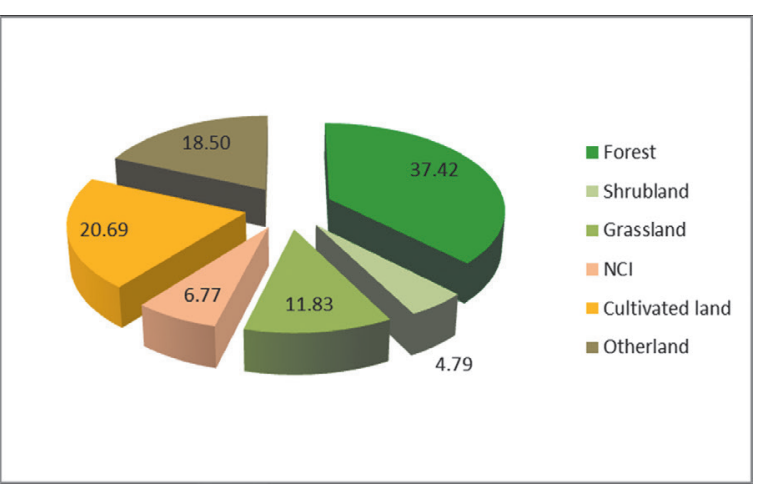

Source: MPFS, 1988

Figure 7: Land use status by MPFS in 1988

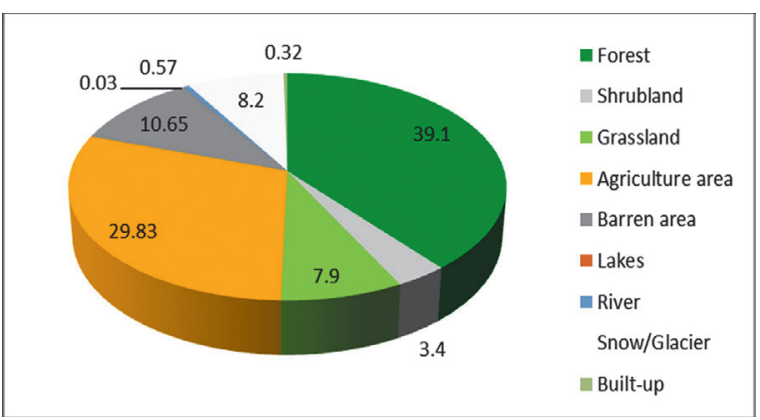

Source: Uddin et al., 2014

Figure 8: Land-use status by ICIMOD in 2010

Nevertheless, this study attempted to test the Collect Earth as a tool to analyze different land cover classes with respect to the earlier assessments. The method of analyzing land cover classes using the Collect Earth could identify larger patches of land cover classes like forest and cropland. Interpretations of other land and grassland were challenging because of their changeability in appearance with changing seasons of the year. In addition, grasslands are the most confusing land cover category to identify in imageries (Zhao et al., 2017). Thus different assessments have provided contrasting estimates of grassland in Nepal. For example, Table 6 below illustrates a decreasing trend of grassland cover in Nepal. However, some changes can be expected due to natural regeneration and succession to shrub-land and forest which have been reported particularly in the mountains. However, other critical factors leading to differences in the estimates in different assessments arise due to the variation in the definition, input data and approach used for estimation and mapping of grasslands. 
Table 6: Grassland cover of Nepal in different studies

\begin{tabular}{|c|c|c|c|}
\hline S.N. & Assessments & Grassland cover $(\%)$ & Reference \\
\hline 1. & Land Resources Mapping Project & 12.00 & LRMP, 1986 \\
\hline 2. & $\begin{array}{l}\text { District, Regional and National Forest } \\
\text { Cover Class Summaries of the Area, } \\
\text { Fuelwood Yield and Wood Volume for the } \\
\text { Kingdom of Nepal }\end{array}$ & 11.90 & WECS, 1988 \\
\hline 3. & Master Plan for the Forestry Sector & 11.83 & MPFS, 1988 \\
\hline 4. & $\begin{array}{l}\text { National Forage \& Grassland Research } \\
\text { Centre, Nepal }\end{array}$ & 11.55 & Pande, 2007 \\
\hline 5. & $\begin{array}{l}\text { Development of } 2010 \text { National Land } \\
\text { Cover Database for Nepal }\end{array}$ & 7.90 & Uddin et al., 2014 \\
\hline
\end{tabular}

The methodology adopted in the assessment of forest and land cover situation of the country can be recognized as a methodology for future monitoring programs. However, developing the national land cover monitoring system using the Google Earth Engine can be a promising effort to consistently acquire the data and information on the periodic land cover status of Nepal. The method can also be convenient to obtain the required datasets for periodic reporting to the UNFCCC and UN-FAO in addition to other internal as well as international reporting.

\section{Conclusion}

The calculated results of forest, cropland, settlement and wetland from this study are reliable for various reporting purposes. However, further studies are necessary to generate more reliable results in terms of grassland and other land. More reliable results can be generated with the use of ancillary datasets along with imageries for all seasons and acquiring a sufficient number of verified field sample points. The results can be further improved by including more frequent time-series observations with the help of highresolution imageries. The findings of this study may be useful for land-use planners in updating the forest and other land cover areas of Nepal and also for scholars and practitioners in using the latest tools and technologies on land cover assessments.

\section{Acknowledgements}

The authors hereby acknowledge Ministry of Forests and Environment, Nepal for endorsing the program under Forest Research and Training Centre, Kathmandu. Furthermore, we express sincere thanks to WWF Nepal/USAID/Hariyo Ban program for funding this study.

\section{References}

Araya, Y. H. and Hergarten, C. 2008. A comparison of pixel and object-based land cover classification : a case study of the Asmara region, Eritrea. WIT Transactions on the Built Environment Volume 100, pp. 233-243.

Aspinall, R. J. and Hill, M. J. 2007. Land use change : science, policy and management. CRC Press.

Bey, A., Sánchez-Paus Díaz, A., Maniatis, D., Marchi, G., Mollicone, D., Ricci, S., Bastin, J. F., Moore, R., Federici, S., Rezende, M. and Patriarca, C. 2016. Collect earth : Land use and land cover assessment through augmented visual interpretation. Remote Sensing 8 (10) : 807.

Bhattarai, K., Conway, D. and Yousef, M. 2009. Determinants of deforestation in Nepal's central development region. Environment Management 91 (2) : 471-488.

Briassoulis, H. 2009. Land use, land cover and soil science-Factors influencing land-use and land-cover change. Encyclopedia of Life Support Systems I : 9. 
Congalton, R. G. 1991. A review of assessing the accuracy of classifications of remotely sensed data. Remote Sensing of Environment 37 (1) : 35-46.

DFRS. 2015. State of Nepal's Forests. Forest Resource Assessment (FRA) Nepal, Department of Forest Research and Survey. Kathmandu, Nepal.

Duro, D. C., Franklin, S. E. and Dubé, M. G. 2012. Multi-scale object-based image analysis and feature selection of multisensor earth observation imagery using random forests. International Journal of Remote Sensing 33 (14) : 4502-4526.

Foody, G. M. and Atkinson, P. M. (eds). 2003. Uncertainty in remote sensing and GIS. John Wiley and Sons.

IPCC. 2003. Good Practice Guidance for Land Use, Land-Use Change and Forestry. IPCC National Greenhouse Gas Inventories Programme, Technical Support Unit, The Inter-Governmental Panel on Climate Change, Hayama, Kanagawa, Japan.

Lei, G., Li, A., Cao, X., Zhao, W., Bian, J., Deng, W. and Koirala, H. L. 2017. Land Cover Mapping and Its Spatial Pattern Analysis in Nepal. In Land Cover Change and Its Eco-environmental Responses in Nepal. Springer, Singapore. pp. 17-39

Li, X. and Shao, G. 2014. Object-Based LandCover Mapping with High-Resolution Aerial Photography at a County Scale in Midwestern USA. Remote Sensing 6 (11) : 11372-11390. Doi : 10. 3390/rs61111372.

LRMP. 1986. Summary Report. Land Resource Mapping Project, His Majesty's Government of Nepal and Government of Canada. Kenting Earth Sciences Limited.

MoFSC. 2014. National Biodiversity Strategy and Action Plan. Ministry of Forests and Soil Conservation, Government of Nepal.
MoLRM. 2015. Land Use Policy. Government of Nepal, Ministry of Land Reform and Management, Singhdurbar, Kathmandu, Nepal.

MPFS. 1988. Master Plan for the Forestry Sector Nepal : Main Report. Ministry of Forests and Soil Conservation, Kathmandu, Nepal.

Openforis. 2018. Collect Earth. Augmented Visual Interpretation for Land Monitoring. [Webpage article]. Online at : http : //www. openforis. org/tools/collect-earth. html. Accessed on $21^{\text {st }}$ October, 2018.

Pande, R. S. 2007. Grassland Resources in Nepal [Blog Article]. National Forage \& Grassland Research Centre, Nepal. Monday, July 9, 2007. http : //nfgrenepal. blogspot. com $/ 2007 / 07 /$ grasslandresources-in-nepal-by. html.

Ramankutty, N. and Foley, J. A. 1999. Estimating historical changes in global land cover : Croplands from 1700 to 1992. Global Biogeochemical Cycles 13 (4) : 997-1027. DOI : 10. 1029/1999GB900046.

Uddin, K., Shrestha, H. L., Murthy, M. S. R., Bajracharya, B., Shrestha, B., Gilani, H., Pradhan, S. and Dongol, B. 2014. Development of 2010 national land cover database for Nepal. Journal of Environmental Management 148 : 82-90.

Wang, H. 2004. Guide to the World States : Nepal. Social Sciences Academic Press (China), Beijing.

WECS. 1988. District, Regional and National Forest Cover Class Summaries of the Area, Fuelwood Yield and Wood Volume for the Kingdom of Nepal, Vol I \& II. Kathmandu.

Zhao, Y., Feng, D., Yu, L., See, L., Fritz, S., Perger, C. and Gong, P. 2017. Assessing and improving the reliability of volunteered land cover reference data. Remote Sensing $9(10): 1034$. 